The Competence of Islamic Religious Education Teachers in Increasing the Potential of Students at Al-Irsyad Islamic Vocational School Kebon Kongok Suka Makmur, West Lombok, West Nusa Tenggara Province

\title{
Kompetensi Guru Pendidikan Agama Islam dalam Meningkatkan Potensi Peserta Didik di SMK Islam Al-Irsyad Kebon Kongok Suka Makmur Lombok Barat Provinsi Nusa Tenggara Barat
}

\author{
Mastur, S.Sos., M.Pd. \\ email: mastur1234@gmail.com
}

Dosen Tetap STIT Darussalimin NW Praya Lombok Tengah - Nusa Tenggara Barat

\begin{abstract}
The purpose of this study is to determine 1). Competence of Islamic Religious Education Teachers in teaching and learning activities at Islamic Vocational High School Al-Irsyad Kebon Kongok, 2). The application of the competence of Islamic religious education teachers in improving student achievement of Islamic Vocational High School AlIrsyad Kebon Kongok. The research method used in this research is qualitative. This means that the resulting data is descriptive, where the researcher does not only collect and compile data but analyzes and interprets it. The data analysis used is inductive descriptive analysis, namely analysis by describing specific events or data to conclude into a general conclusion. Based on the results of the data analysis carried out, the following data were obtained, namely the learning outcomes of students in the field of Islamic Religious Education the average score was 71.63 , the learning outcomes of the students in the field of study aqidah morals the average score was 71.10 , then the learning outcomes of students in the field of Islamic religious education, the average was 75.33, and the English learning outcome score was 70.78 . By looking at these results we can say that the competence possessed by the Islamic Religious Education teacher at the Islamic Vocational School Al-Irsyad Kebon Kongok Suka Makmur, Gerung District, West Lombok, West Nusa Tenggara Province is sufficient to improve student learning achievement because the results obtained have met the completeness standards. minimal.
\end{abstract}

Keywords: Teacher Competence, Islamic Religious Education, Student Potential

\begin{abstract}
Abstrak: Tujuan dari penelitian ini adalah untuk mengetahui 1). Kompetensi Guru Pendidikan Agama Islam dalam kegiatan belajar mengajar di SMK Islam Al-Irsyad Kebon Kongok, 2). Penerapan Kompetensi Guru Pendidikan Agama Islam dalam meningkatkan prestasi belajar siswa SMK Islam Al-Irsyad Kebon Kongok. Metode
\end{abstract}

$$
85 \text { | Edisi } 3 \text { No.1 Agustus } 2020 \text {-Januari } 2021
$$


penelitian yang digunakan dalam penelitian ini adalah metode kualitiatif. Artinya bahwa data yang dihasilkan bersifat deskriftif, dimana peneliti tidak hanya mengumpulkan dan menyusun data,tetapi menganalisis dan menginterpretasiknnya. Analisis data yang digunakan adalah analisis deskriftif induktif, yaitu analisis dengan mnguraikan peristiwa-peristiwa atau data-data yang bersifat khusus untuk kemudian menyimpulkan menjadi satu kesimpulan yang umum. Berdasarkan hasil analisis data yang dilakukan, diperoleh data sebagai berikut, yaitu hasil belajar siswa bidang studi Pendidikan Agama Islam nilai rata-ratanya adalah 71.63 , hasil belajar siswa bidang studi aqidah akhlak nilai rata-ratanya adalah 71.10 , kemudian hasil belajar siswa bidang studi fiqih nilai rata-ratanya adalah 75.33 , dan nilai hasil belajar bahasa Inggris dengan rata-rata sesesar 70.78. dengan melihat hasil tersebut dapat kita mengatakan bahwa kompetensi yang dimiliki oleh guru Pendidikan Agama Islam di SMK Islam Al-Irsyad Kebon Kongok Suka Makmur Kecamatan Gerung Lombok Barat Provinsi Nusa Tenggara Barat sudah cukup memadai untuk meningkatkan prestasi belajar siswa karena hasil yang diperoleh sudah memenuhi standar ketuntasan minimal.

Kata Kunci: Kompetensi Guru, Pendidikan Agama Islam, Potensi Peserta Didik

\section{A. Pendahuluan}

Pendidikan pada dasarnya merupakan interaksi antara pendidik dengan peserta untuk mencapai tujuan pendidikan yang berlangsung dalam lingkungan tertentu, interaksi ini disebut dengan intraksi pendidikan. Sedangkan pendidikan itu berfungsi membantu peserta didik dalam pengembangan dirinya, yaitu pengembangan semua potensi, kecakapan, serta karakteristik pribadinya kearah yang positif baik bagi dirinya maupun lingkungannya. Pendidikan juga berfungsi untuk mengembangkan apa yang secara potensial dan aktual dimiliki oleh peserta didik. Kaitannya dengan hal ini, dalam undang-undang nomor 20 tahun 2003 tentang sistem pendidikan nasional, pada bab 1 tentang ketentuan umum pasal 1 ayat (1) menyebutkan bahwa: Pendidikan adalah usaha sadar dan terencana untuk mewujudkan suasana belajar dan proses pembelajaran agar peserta didik secara aktif mengembangkan potensi dirinya untuk memiliki kekuatan spritual keagamaan, pengendalian diri, keperibadian, kecerdasan, akhlak mulia, serta keterampilan, yang diperlukan dirinya, masyarakat, bangsa dan negara. Selain itu Pendidikan Agama Islam secara umum dapat diartikan sebagai usaha sadar untuk mengarahkan pertumbuhan dan perkembangan anak dengan segala potensi yang dianugrahi Allah kepadanya agar mampu mengemban dan tanggung jawab sebagai khalifah Allah di bumi dalam pengabdiannya kepada Allah SWT. (Nana S, 2004:26). Secara umum disebutkan peserta didik memiliki tiga potensi, yaitu potensi nilai dan sikap (afektif) potensi intelektual (kognitif), dan potensi fisik manual dan potensi inderawi (psikomotorik). (Heri S, 2005:25).

\section{6|Edisi 3 No.1 Agustus 2020 -Januari 2021}


Dalam dunia pendidikan potensi dapat diartikan sebagai modal dasar sesuatu yang siap berkembang dan dikembangkan. Potensi itu akan dapat berkembang apabila dikembangkan oleh seorang pendidik. Seandainya manusia tidak memiliki potensi, maka secara otomatis tidak diperlukan adanya pendidik, karena potensi itu merupakan modal dasar sebagai pendidik dalam mengembangkan potensi peserta didik itu sendiri. Dalam melaksanakan Pendidikan Agama Islam, komptensi dan tugas pendidik sangat penting, karena dia yang bertanggung jawab dan menentukan arah pendidikan tersebut, seorang pendidik harus memiliki nilai lebih (nilai plus) dibandingkan peserta didik. Nilai lebih yang harus dimiliki oleh seorang pendidik Islam mencakup tiga hal pokok, yaitu pengetahuan keterampilan dan keperibadian yang didasarkan nilai-nilai ajaran Islam. Tanpa ini semua sulit bagi pendidik untuk dapat mengembangkan potensi peserta didik, terutama dalam intraksi pendidikan. Oleh karena itu nilai lebih/komptensi itu mutlak diperlukan guru dalam melaksanakan tugasnya sebagai pendidik. Tugas dan kompetensi yang harus dilaksanakan dan dimiliki oleh seseorang Guru Agama Islam adalah: (1) Tugas Pengajaran, (2) Tugas bimbingan dan penyuluhan, dan (3) Tugas administrasi. Sedangkan kompetensi yang harus dimiliki oleh pendidik Islam antara lain: (1) Kompetensi keperibadian, (2) Kompetensi penguasaan atas bahan pengajaran, dan (3) Kompetensi dalam caracara mengajar.

Kesemua itu mencakup pada perkembangan dalam domain afektif, kognitif, dan psikomotorik, perkembangan potensi peserta didik dalam semua bidang ini didukung juga dengan adanya berbagai macam kegiatan ekstrakulikuler yang telah diprogramkan oleh lembaga pendidikan ini. Dengan konsep inilah, sehingga penulis merasa tertarik untuk mengadakan penelitian yang dituangkan dalam bentuk karya ilmiah yang berjudul tugas dan Kompetensi Guru Pendidikan Agama Islam dalam meningkatkan potensi peserta didik dengan pengangkatan judul seperti ini diharapkan agar para pendidik Agama Islam dapat lebih meningkatkan kompetensi yang ia miliki serta dapat melaksanakan tugas dan kewajibannya secara optimal, sehingga prestasi dan pendidikan peserta didik dapat lebih berkembang, lebih tinggi, lebih berkualitas yang disertai dengan keimanan dan ketaqwaan kepada Tuhan Yang Maha Esa sesuai dengan tujuan Pendidikan Nasional.

Menurut (WJS. Purwadarmmta) dalam kamus umum Bahasa Indonesia, kompetensi berarti kewenangan atau kekuasaan untuk menentukan atau memutuskan suatu hal. Sedangkan pengertian dasar kompetensi adalah kemampuan atau kecakapan. (Moh, Uzer U, 2001:14). Kompetensi merupakan suatu istilah yang memiliki banyak makna, diantaranya adalah kompetensi merupakan perpaduan dari pengetahuan, keterampilan, nilai dan sikap yang direfleksikan dalam kebiasaan berfikir dan bertindak. (Mc. Ashan), mengemukakan bahwa kompetensi diartikan sebagai pengetahuan, keterampilan dan kemampuan yang dikuasai oleh seseorang yang telah menjadi bagian dari dirinya, sehingga ia dapat melakukan perilaku-perilaku kognitif, afektif, dan psikomotorik dengan sebaik-baiknya. sejalan dengan itu, Finch dan Crunkilton mengartikan kompetensi sebagai penguasaan terhadap suatu tugas, keterampilan, sikap dan apresiasi yang diperlukan untuk menunjang keberhasilan. (E.Mulyasa, 2004:37). Adapun

$$
\text { 87 Edisi } 3 \text { No.1 Agustus } 2020 \text {-Januari } 2021
$$


kompetensi guru merupakan kemampuan seorang guru dalam melaksanakan kewajiban-kewajiban secara bertanggungjawab dan layak.

Guru dalam penyelenggaraan Pendidikan Agama Islam pada hakikatnya adalah mereka yang melaksanakan tugas dan tanggung jawab mendidik. Dalam Islam, pengertian mendidik tidak hanya dibatasi pada terjadinya interaksi pendidikan dan pembelajaran antara guru dan peserta didik di kelas, tetapi mengajak, mendorong dan membimbing orang lain untuk memahami dan melaksanakan ajaran lain merupakan bagian dari aktivitas Pendidikan Agama Islam. Oleh karena itu, aktivitas Pendidikan Agama Islam dapat berlangsung kapan dan dimana saja, bahkan oleh siapa saja sepanjang yang bersangkutan memenuhi syarat-syarat baik dilihat dari prinsip-prinsip pendidikan dan pembelajaran maupun ajaran Islam. Walaupun prinsip-prinsip dasar pendidik Islam itu pada hakikatnya sama untuk semua aktivitas Pendidikan Agama Islam, tentu saja secara teknis terdapat beberapa perbedaan yang disesuaikan dengan kualifikasi kelembagaan penyelenggara. Pendidikan Agama Islam yang diselenggarakan dilingkungan keluarga tidak persis sama kualifikasi pendidikannya dengan Pendidikan Agama Islam yang dilaksanakan dilembaga pendidikan sekolah atau masyarakat, demikian pula. Sebaliknya Pendidikan Agama Islam yang melaksanakan tugas dilembaga-lembaga pendidikan sekolah harus memenuhi kualifikasi atau persyaratan yang lebih ketat jika dibandingkan dengan pendidik Islam dalam keluarga atau masyarakat, karena pola pengembangan pendidikan dan pembelajaran dilembaga sekolah menurut sejumlah ketentuan dan persyaratan teknis yang dilembaga pendidikan keluarga dan masyarakat hal itu tidak dibutuhkan. (Ahmad, S, 2005:35). Mengenai tugas dan kompetensi guru dalam masalah ini akan difokuskan mengenai pendidik dalam lembaga Pendidikan di Sekolah.

Adapun mengenai tugas guru, dalam Undang-Undang Sistem Pendidikan, Nasional. Pasal 27 ayat (3) dikemukakan bahwa guru adalah tenaga pendidik yang khusus diangkat dengan tugas utama mengajar. Di samping itu, ia mempunyai tugas lain yang bersifat pendukung, yaitu membimbing dan mengelola administrasi sekolah. Tiga tugas ini mewujudkan tiga layanan yang harus diberikan oleh guru kepada peserta didik dan tiga peranan yang harus dijalankannya. Tiga layanan yang dimaksud ialah: (1) Layanan Instruksional, (2) Layanan bantuan, dan (3) Layanan administrasi.

Adapun tiga peranan guru ialah: (1) Sebagai pengajar, (2) Sebagai pembimbing, dan (3) Sebagai administrator kelas. Sebagai pengajar, guru mempunyai tugas menyelenggarakan proses belajar-mengajar. Tugas yang mengisi porsi terbesar dari profesi keguruan ini pada garis besarnya meliputi empat pokok yaitu: (1) Menguasai bahan pengajaran, (2) Merencanakan program belajar mengajar, (3) Melaksanakan, memimpin, dan mengelola proses belajar-mengajar, dan (4) Menilai kegiatan belajar mengajar. (Depag, 2002:26).

Menurut N.A. Ametembun, guru adalah semua orang yang berwenang dan bertanggungjawab terhadap pendidikan siswa baik secara Individual ataupun klasikal, baik di sekolah maupun di luar sekolah, ini berarti seorang guru minimal memiliki dasar-dasar kompetensi sebagai wewenang dan kemampuan dalam menjalankan tugas. Untuk itu seorang guru perlu memiliki kepribadian, menguasai

$$
\text { 88| Edisi } 3 \text { No.1 Agustus } 2020 \text {-Januari } 2021
$$


bahan pelajaran dan menguasai cara-cara mengajar sebagai dasar kompetensi. Bila guru tidak memiliki kepribadian, tidak menguasai bahan dan cara-cara mengajar, maka guru gagal menunaikan tugasnya, sebelum berbuat banyak dalam pendidikan dan pengajaran. Oleh karena itu, kompetensi mutlak dimiliki guru sebagai kemampuan, kecakapan atau keterampilan dalam mengelola kegiatan pendidikan. Dengan demikian, kompetensi guru berarti pemilikan pengetahuan keguruan dan pemilikan keterampilan serta kemampuan sebagai guru dalam, melaksanakan tugasnya. (Syaiful B, 1994:33). Kompetensi sebagai bagian yang integral yang tidak terpisahkan dari diri guru sebagai pendidik memang suatu hal yang mutlak dimiliki guru dan bahkan dikuasai. Pada dasarnya guru harus memiliki tiga kompetensi yaitu kompetensi kepribadian, kompetensi penguasaan atas bahan dan kompetensi dalam cara-cara mengajar (Moh. Uzer Usman, 2001:14).

Ketiga aspek kompetensi tersebut di atas harus berkembang secara selaras dan tumbuh terbina dalam kepribadian guru. Dengan demikian itu dapat diharapkan dari padanya untuk mengarahkan segala kemampuan dan keterampilannya dalam mengajar secara profesional dan efektif, (Zakiyah D, 2004:263).

Dalam pasal ayat 6 Undang-Undang RI Nomor 2 tahun 1989 tentang Sistem Pendidikan Nasional merumuskan pengertian bahwa, peserta didik adalah anggota masyarakat yang berusaha mengembangkan dirinya melalui proses pendidikan pada jalur, jenjang dan jenis pendidikan tertentu.

Hal ini menggambarkan bahwa anak didik adalah mereka yang belum memiliki pengetahuan, keterampilan dan kepribadian, karena ketika dilahirkan mereka tidak membawa bekal pengetahuan, keterampilan dan keterampilan yang dibutuhkannya kelak. Dalam ketentuan umum Undang-Undang Pendidikan Nasional tahun 2003 pasal 1 ayat 1 dikemukakan bahwa pendidikan adalah usaha sadar dan terencana untuk mewujudkan suasana belajar dan proses pembelajaran agar peserta didik secara aktif mengembangkan potensi dirinya untuk memiliki kekuatan spiritual keagamaan, pengendalian diri, kepribadian, kecerdasan, akhlak mulia, serta keterampilan yang diperlukan dirinya, masyarakat, bangsa dan negara. (Nana S, 2004:26).

\section{B. Metode Penelitian}

Dalam kegiatan penelitian ini, penditi bertujuan untuk menggunakan jenis penelitian kualitatif. Untuk mengadakan pengkajian terhadap istilah penelitian kualitatif. Dalam melakukan penelitian secara eksperimental maka perlu sekali diketahui desain-desain yang sering digunakan dalam penelitian tersebut. Dengan desain yang baik, maka pengaturan variabel-variabel dan kondisi-kondisi eksperimental dapat dilakukan secara seksama, ketat dan tertib. Secara sempit, desain penelitian sering ditafsirkan sebagai suatu proses merencanakan percobaan, sehingga hasil yang diperoleh dari percobaan ini dapat memecahkan masalah secara mantap. Tetapi sebenarnya, desain percobaan bukan saja memberikan proses perencanaan, tetapi juga mencakup langkah-langkah yang berurutan, menyeluruh, komplit, dibuat lebih dahulu, serta cara pelaksanaan percobaan, supaya peneliti yakin bahwa data yang diperoleh dapat dianalisis

$$
\text { 89|Edisi } 3 \text { No.1 Agustus } 2020 \text {-Januari } 2021
$$


secara objektif dan dapat digunakan untuk mengadakan suatu interferensi yang valid berkenaan dengan masalah yang sedang diselidiki. (Moh. Nazir, 2003:221).

\section{Kehadiran Penelitian}

Untuk memperoleh data tentang penelitian yang dilakukan dengan menggunakan penelitian kuantitatif, maka peneliti hendaknya dapat terjun langsung ke lapangan dan memang mutlak untuk dilakukan sebab penelitian tersebut akan lebih banyak berbicara masalah fenomena-fenomena atau realita dilapangan. Kehadiran penelitian dalam penelitian ini berperan sebagai instrumen kunci yang langsung melibatklan diri dalam kehidupan subyek dalam waktu penelitian yang sudah ditetapkan peneliti. Sesuai dengan ciri penelitian kualitatif yaitu salah satunya adalah peneliti sebagai instrumen kunci maka seperti ini kehadiran penelitian di lapangan sangat mutlak dilakukan oleh peneliti sendiri.

Berangkat dari hal semacam itu maka dalam pengumpulan data peneliti berusaha menciptakan hubungan yang akrab dengan responden yang menjadi sumber data, agar data yang diperoleh betul-betul valid untuk dapat menciptakan hubungan yang akrab peneliti berusaha agar dapat diterima, untuk itu sebelum peneliti hadir dilapangan seharusnya sudah memperoleh izin terlebih dahulu dari pihak-pihak yang bertanggungjawab sesuai dengan prosedur yang berlaku. Dalam hal kehadiran peneliti dilapangan bukanlah bertujuan mempengaruhi kehidupan subyek yang diteliti, akan tetapi hanya untuk mendapatkan data yang akurat mengenai hal-hal yang ingin diperoleh dan dicapai peneliti sendiri.

\section{Populasi dan Sampel Penelitian}

\section{Populasi}

Populasi adalah keseluruhan subjek penelitian. Apabila seseorang ingin meneliti semua elemen yang ada dalam wilayah penelitian, maka penelitiannya merupakan penelitian populasi, studi atau penelitiannya juga disebut studi populasi atau studi kasus. Penelitian populasi dilakukan apabila peneliti ingin melihat semua liku-liku yang ada di dalam populasi. Oleh karena itu, subjeknya meliputi semua yang terdapat di dalam populasi maka juga disebut sensus. Dilihat dari jumlahnya, pupulasi dapat dibagi dalam:

a) Jumlah terhingga, terdiri dari elemen dengan jumlah tertentu. Seperti contoh nomor 1,2 dan 3.

b) Jumlah tak terhingga, terdiri dari elemen yang sukar sekali di cari batasannya.

Objek pada populasi diteliti, hasilnya dianalisis, disimpulkan dan kesimpulan itu berlaku untuk seluurh populasi. Sehingga penelitian populasi hanya dapat dilakukan bagi populasi terhingga dan subjeknya tidak terlalu banyak.

\section{Sampel}

Sampel adalah sebagian atau wakil populasi yang diteliti. Dinamakan penelitian sampel apabila kita bermaksud untuk menggeneralisasikan hasil penelitian sampel. Penelitian sampel baru boleh dilaksanakan apabila keadaan subjek di dalam populasi benar-benar homogen. Apabila subjek populasi tidak omogen, maka kesimpulannya tidak boleh diberlakukan bagi seluruh populasi hasilnya tidak boleh digeneralisasikan. (Arikunto Suharsimi, 2006:130).

Adapun yang akan menjadi sumber informasi dalam kegiatan penelitian ini adalah setiap pendidik/guru yang khususnya bergelut dalam bidang pendidikan

$$
\text { 90|Edisi } 3 \text { No.1 Agustus } 2020-J \text { anuari } 2021
$$


yang dimiliki tingkat kemampuan atau potensi tinggi yang dihasilkan dari proses pendidikan di SMK Islam Al-Irsyad Kebon Kongok Suka Makmur Kecamatan Gerung Lombok Barat Provinsi Nusa Tenggara Barat. Penelitian dilakukan bagi guru pendidik agama yang memiliki kompeten dalam mengembangkan potensi peserta didik dalam lembaga pendidikan ini.

\section{Metode Pengumpulan Data}

Pada bagian ini merupakan langkah-langkah dan tehnik yang ditempuh peneliti untuk mempermudah proses dalam mendapatkan semua data yang diperlukan nantinya, dengan tehnik seperti ini peneliti dapat mengkualifikasi dan menjumlahkan unsur-unsur yang terkait dalam proses pengumpulan data. Pengumpulan data tidak lain dari suatu proses pengadaan data primer untuk keperluan penelitian. pengumpulan data merupakan langkah yang penting dalam metode ilmiah sebagai mana dikemukakan oleh Nazir bahwa pengumpulan data adalah prosedur yang sistimatik dan standar untuk memperoleh data yang diperlukan. (M.Nazir, 1999:24). Ada beberapa metode untuk mengumpulkan data dalam suatu penelitian ilmiah, yang mana metode ini dipilih sesuai dengan kebutuhan dari peneliti sendiri. Adapun tehnik atau metode pengumpulan data yang dipergunakan peneliti dalam penelitian ini adalah, 1). Metode observasi, metode wawancara dan metode dokumentasi

\section{Teknik Analisis Data}

Analisis data merupakan bagian yang amat penting dalam metode ilmiah. Karena dengan analisis data tersebut dapat diberi arti dan makna yang berguna dalam memecahkan masalah penelitian. Setelah data terkumpul dari hasil pengumpulan data, perlu segera digarap oleh peneliti. Secara garis besar analisis data meliputi 3 langkah yaitu penerapan data sesuai dengan pendekatan penelitian.

\section{Persiapan}

Kegiatan dalam langkah persiapan ini antara lain:

a. Mengecek nama dan kelengkapan identitas pengisi

b. Mengecek kelengkapan data, artinya memeriksa isi instrumen pengumpulan data.

2. Tabulasi

Kegiatan tabulasi ini antara lain:

a. Memberikan skor terhadap item-item yang perlu di beri skor

b. Memberikan kode terhadap item-item yang tidak di beri skor

c. Mengubah jenis data, disesuaikan atau dimodifikasi dengan teknik analisis yang akan digunakan.

d. Memberikan kode dalam hubungan dengan pengolahan data jika akan menggunakan komputer.

3. Penerapan data sesuai dengan pendekatan penilaian

Data yang diterapkan dalam perhitungan adalah data yang di sesuaikan dengan jenis data, yakni diskrit, ordinal interaktual dan ratio. Pemilihan terhadap rumus yang digunakan kadang-kadang disesuaikan dengan jenis data, tetapi adakalanya peneliti menentukan pendekatan, Kemudian data yang ada diubah disesuaikan dengan rumus yang sudah dipilih. (Moh. Nazir,2003:235).

\section{Edisi 3 No.1 Agustus 2020 -Januari 2021}




\section{Hasil Penelitian}

\section{Kompetensi Guru Pendidikan Agama Islam dalam kegiatan belajar mengajar di SMK Islam Al-Irsyad Kebon Kongok}

Kompetensi kepribadian merupakan kemampuan personal yang mencerminkan kepribadian yang mantap, stabil, dewasa, arif, dan berwibawa, menjadi teladan bagi peserta didik, dan berakhlak mulia. Secara rinci setiap elemen kepribadian tersebut dapat dijabarkan menjadi sub kompetensi dan indikator esensial sebagai berikut: (a). Memiliki kepribadian yang mantap dan stabil. Subkompetensi ini memiliki indikator esensial: bertindak sesuai dengan norma hukum; bertindak sesuai dengan norma sosial; bangga sebagai pendidik; dan memeliki konsistensi dalam bertindak sesuai dengan norma. (b). Memiliki kepribadian yang dewasa. Subkompetensi ini memiliki indikator esensial: menampilkan kemandirian dalam bertindak sebagai pendidik dan memiliki etos kerja sebagai pendidik. (c). Memiliki kepribadian yang arif. Sub kompetensi ini memiliki indikator esensial: menampilkan tindakan yang didasarkan pada kemanfaatan peserta didik, sekolah, dan masyarakat dan menunjukkan keterbukaan dalam berpikir dan bertindak. (d). Memiliki kepribadian yang berwibawa. Subkompetensi ini memiliki indikator esensial: memiliki perilaku yang berpengaruh positif terhadap peserta didik dan memiliki perilaku yang disegani. (e). Memiliki akhlak mulia dan dapat menjadi teladan. Subkompetensi ini memiliki indikator esensial: bertindak sesuai dengan norma religius (imtaq, jujur, ikhlas, suka menolong), dan memiliki perilaku yang diteladani peserta didik.

\section{Kompetensi Pedagogik}

Kompetensi pedagogik merupakan kemampuan yang berkenaan dengan pemahaman peserta didik dan pengelola pembelajaran yang mendidik dan dialogis. Secara substantif kompetensi ini mencakup kemampuan pemahaman terhadap peserta didik, perancangan dan pelaksanaan pembelajaran, evaluasi hasil belajar, dan pengembangan peserta didik untuk mengaktualisasikan berbagai potensi yang dimilikinya. Secara rinci masing-masing elemen kompetensi pedagogik tersebut dapat dijabarkan menjadi subkompetensi dan indikator esensial sebagai berikut: (a) Memahami peserta didik. Subkompetensi ini memiliki indikator esensial: memamahami peserta didik dengan memanfaatkan prinsipprinsip perkembangan kognitif, memahami peserta didik dengan memanfaatkan prinsip-prinsip kepribadian; dan mengidenti- fikasi bekal-ajar awal peserta didik. (b) Merancang pembelajaran, termasuk memahami landasan pendidik-an untuk kepentingan pembelajaran. Subkompetensi ini memiliki indikator esensial: menerapkan teori belajar dan pembelajaran; menentukan strategi pembelajaran berdasarkan karakteristik peserta didik, kompetensi yang ingin dicapai, dan materi ajar; serta menyusun rancangan pembelajaran berdasarkan strategi yang dipilih. (c) Melaksanakan pembelajaran. Subkompetensi ini memiliki indikator esensial: menata latar (setting) pembelajaran; dan melaksanakan pembelajaran yang kondusif. (d) Merancang dan melaksanakan evaluasi pembelajaran. Subkompetensi ini memiliki indikator esensial: melaksanakan evaluasi (assess-ment) proses dan hasil belajar secara berkesinambungan dengan berbagai metode; menganalisis hasil penilaian proses dan hasil belajar untuk menentukan tingkat 
ketuntasan belajar (mastery level); dan memanfaatkan hasil penilaian pembelajaran untuk perbaikan kualitas program pembelajaran secara umum. (e) Mengembangkan peserta didik untuk mengaktualisasikan berbagai potensi yang dimilikinya.

\section{Kompetensi Profesional}

Kompetensi professional merupakan kemampuan yang berkenaan dengan penguasaan materi pembelajaran bidang studi secara luas dan mendalam yang mencakup penguasaan substansi isi materi kurikulum matapelajaran di sekolah dan substansi keilmuan yang menaungi materi kurikulum tersebut, serta menambah wawasan keilmuan sebagai guru. Secara rinci masing-masing elemen kompe-tensi tersebut memiliki subkompetensi dan indikator esensial sebagai berikut: (a) Menguasai substansi keilmuan yang terkait dengan bidang studi. Subkompetensi ini memiliki indikator esensial: memahami materi ajar yang ada dalam kurikulum sekolah; memahami struktur, konsep dan metode keilmuan yang menaungi atau kohe-ren dengan materi ajar; memahami hubungan konsep antarmata pelajaran terkait; dan menerapkan konsep-konsep keilmuan dalam kehidupan sehari-hari. (b) Menguasai langkah-langkah penelitian dan kajian kritis untuk me-nambah wawasan dan memperdalam pengetahuan/materi bidang studi.

\section{Kompetensi Sosial}

Kompetensi sosial berkenaan dengan kemampuan pendidik sebagai bagian dari masyarakat untuk berkomunikasi dan bergaul secara efektif dengan peserta didik, sesama pendidik, tenaga kependidikan, orangtua/wali peserta didik, dan masyarakat sekitar.Kompetensi ini memiliki subkompetensi dengan indikator esensial sebagai berikut: (a) Mampu berkomunikasi dan bergaul secara efektif dengan peserta didik. Subkompetensi ini memiliki indikator esensial: berkomunikasi secara efektif dengan peserta didik. (b) Mampu berkomunikasi dan bergaul secara efektif dengan sesama pendidik dan tenaga kependidikan. (c) Mampu berkomunikasi dan bergaul secara efektif dengan orang tua/wali peserta didik dan masyarakat sekitar.

\section{Hasil Penerapan Kompetensi Guru}

Kegiatan belajar mengajar merupakan suatu usaha untuk membantu peserta didik dalam mengembangkan dirinya, yaitu perkembangan prestasi belajar, kecakapan, serta karakteristik pribadinya kearah yang positif baik bagi dirinya maupun lingkungannya. Selain itu kegiatan belajar mengajar juga berfungsi untuk mengembangkan apa yang secara prestasi belajaral dan aktual dimiliki oleh peserta didik. Usaha pengembangan prestasi belajar dan keperibadian peserta didik dalam hal ini tentunya sangat dipengaruhi oleh pelaksanaan tugas dan kompetensi guru secara maksimal. Tugas utama seorang guru adalah mengajar, yaitu tugas menyelenggarakan proses belajar mengajar, di samping itu guru juga mempunyai tugas yang bersifat pendukung seperti tugas membimbing, yaitu tugas untuk memberi bimbingan kepada peserta didik dalam memecahkan masalah yang dihadapinya, sebab proses belajar peserta didik berkaitan erat dengan berbagai masalah di luar kelas yang sifatnya non akademis. Kemudian tugas mengelola administrasi sekolah yaitu tugas yang mencakup ketatalaksanaan pada umumnya seperti mengelola kelas, memanfaatkan prosedur dan mekanisme 
pengelolaan tersebut untuk melancarkan tugasnya serta bertindak sesuai dengan etika jabatan.

Dalam penjabaran mengenai kompetensi guru Pendidikan Agama Islam dalam mengembangkan prestasi belajar peserta didik, ust. H. Zainul Irfan, S.Pd., MM., sebagai kepala sekolah saat diwawancarai penulis waktu mengadakan penelitian mengatakan bahwa: Tugas guru itu adalah mengajar, mendidik dan membentuk kepribadian siswa supaya menjadi manusia yang cerdas terutama bagi guru agama disamping certas, siswanya juga harus menjadi pribadi yang beriman dan bertaqwa kepada Allah. Oleh karena itu, dalam menjalankan tugasnya mengajar guru tersebut sangat dituntut untuk memiliki kedisiplinan dan tanggung jawab sepenuhnya. Kompetensi guru merupakan suatu yang harus ada pada setiap guru. Baik guru bidang studi agama maupun umum. Dengan adanya kompetensi pada guru, diharapkan tujuan pendidikan nasional dapat tercapai karena berhasil atau tidaknya siswa dalam pembelajaran sangat dipengaruhi oleh tinggi atau rendahnya kompetensi yang dimiliki oleh guru yang mengajarnya. Dengan pernyataan ini juga dapat diambil pemahaman bahwa tinggi rendahnya prestasi belajar yang dimiliki siswa ternyata sangat dipengaruhi oleh tinggi rendahnya kompetensi yang dimiliki guru.

Pada hari yang sama, penulis juga melakukan wawancara dengan seorang guru bidang studi agama di SMK Islam Al-Irsyad Kebon Kongok Suka Makmur Kecamatan Gerung Lombok Barat Provinsi Nusa Tenggara Barat yaitu: H. Zainul Irfan, S.Pd., MM., tentang upaya pelaksanaan tugas dan kompetensi guru menyatakan bahwa: Sebagai seorang guru tentunya punya keinginan untuk bisa lebih maju dan semakin berkembang. Sehingga dengan demikian guru merasa berkewajiban untuk tetap meningkatkan kemampuan kompetensi yang ia miliki dalam upaya perkembangan tersebut meskipun tidak semua siswa dapat menerima dengan baik. Selain itu guru juga berkewajiban untuk melaksanakan tugas dan kewajiban dengan penuh tanggung jawab dan dengan disiplin yang tinggi karena seorang guru akan menajdi contoh yang baik dalam membentuk kepribadian yang baik bagi siswa. Berdasarkan hasil wawancara tersebut dapat kami uraikan bahwa upaya yang dilakukan guru dalam melaksanakan tugas dan kompetensinya dalam meningkatkan prestasi belajar peserta didik adalah antara lain:

\section{Disiplin dan Tanggung Jawab Mengajar}

Di dalam memberikan pelajaran kepada peserta didik seorang guru harus melaksanakan tugas dengan penuh tanggung jawab dan dengan disiplin yang tinggi. Sikap disiplin juga harus diterapkan bagi semua peserta didik. Karena tanggung jawab yang besar untuk membentuk keperibadian peserta didik adalah ada di tangan para guru terutama bagi guru agama. Adapun langkah-langkah yang diupayakan guru Pendidikan Agama Islam adalah: (a) Dengan memberikan motivasi atau dorongan kepada peserta didik dimana dengan adanya motivasi diri guru akan sangat mendukung bagi perkembangan intelektual peserta didik, (b) Di samping tetap memberikan motivasi seorang guru juga tetap mengontrol keadaan peserta didalam proses kegiatan belajar mengajar. Karena tanpa adanya pengontrolan tentunya peserta didik akan belajar dengan semaunya, dan (c)

\section{4|Edisi 3 No.1 Agustus 2020 -Januari 2021}


Dengan memberikan penilaian terhadap berhasil atau tidaknya peserta didik dalam menerima pelajaran yang diberikan kepadanya.

\section{Metode yang diterapkan}

\section{a. Metode Ceramah}

Metode ceramah merupakan metode yang paling banyak dan paling sering dipakai oleh guru dalam menyampaikan materi pelajaran terutama bagi mata pelajaran yang membutuhkan penjelasan secara lisan, selain itu dalam waktu yang bersamaan guru dapat menggunakan alat-alat pembantu seperti gambar dan secara langsung dapat pula menjawab setiap pertanyaan dari peserta mengenai penyajian materi pelajaran tersebut.

\section{b. Metode Diskusi}

Metode diskusi adalah cara mengajar dengan jalan mendiskusikan suatu topik dari mata pelajaran tertentu, sehingga menimbulkan pemahaman serta perubahan tingkah laku peserta didik. Dalam metode ini semua anak diikut sertakan secara aktif untuk mencari pemecahan tentang topik tersebut. Metode ini juga lebih efektif untuk mendatangkan kepahaman kepada semua peserta didik serta dapat membuat suasana kelas menjadi hidup karena peserta didik dapat mengarahkan perhatian dan pikiran sepenuhnya kepada materi pelajaran.

c. Metode Menghapal

Metode menghafal merupakan bagian dari pemberian tugas karena menghapal adalah suatu tugas yang diberikan guru kepada peserta didik di luar jam pelajaran. Metode ini diterapkan dalam mata pelajaran Agama Islam terutama yang mengandung dan terkait dengan Pendidikan Agama Islam. Dengan metode ini akan memudahkan peserta didik dalam memperaktekkan pelajaran yang telah diterima sehingga membentuk keperibadian yang mantap bagi mereka. Selain ketiga metode di atas, guru Pendidikan Agama Islam di SMK Islam Al-Irsyad Kebon Kongok Suka Makmur Kecamatan Gerung Lombok Barat Provinsi Nusa Tenggara Barat juga mempergunakan metode-metode lain secara bervariasi, akan tetapi karena mata pelajaran Pendidikan Agama Islam lebih efektif dengan ketiga metode di atas oleh karena itulah metode-metode ini lebih sering dipakai dan diterapkan.

\section{Motivasi dalam Mengajar}

Tercapainya tujuan pendidikan merupakan sesuatu yang diinginkan oleh setiap pendidik. Terbentuknya keperibadian yang mentap, pribadi yang beriman dan bertaqwa kepada Tuhan, pribadi yang tampil, amanah dan tanggung jawab merupakan bagian dari tujuan Pendidikan Agama Islam. Oleh karena itu sebagai seorang pendidik agama merasa sangat bertanggung jawab untuk tercapainya tujuan tersebut dengan memotivasi diri melaksanakan tugas dengan sebaikbaiknya. Terkadang di dalam mengajar ada suatu tekanan bagi peserta didik yang malas untuk belajar, karena kalau tidak ada penekanan belajar bagi yang malas maka perkembangan prestasi belajar tidak akan bisa berkembang secara merata kepada semua peserta didik.

Dengan upaya yang dilakukan oleh guru-guru Pendidikan Agama Islam SMK Islam Al-Irsyad Kebon Kongok Suka Makmur Kecamatan Gerung Lombok Barat tersebut menunjukkan adanya pelaksanaan tugas dan kompetensi dengan baik dan sangatlah wajar apabila prestasi belajar peserta didik dapat berkembang

$$
\text { 95 | Edisi } 3 \text { No.1 Agustus } 2020-J \text { anuari } 2021
$$


dengan baik pula, serta untuk masa-masa yang akan datang berkembang dengan baik pula, serta untuk masa-masa yang akan datang dapat diharapkan untuk menjadi semakin berkembang dan meningkat sesuai dengan tujuan yang diinginkan. Dalam penelitian ini data yang dibutuhkan penulis adalah data nilai peserta didik yang memiliki Prestasi yang cukup tinggi dalam bidang mata pelajaran Pendidikan Agama Islam, khususnya data nilai tinggi dalam mata pelajaran Pendidikan Agama Islam. Dimana tingginya nilai yang dimiliki ini merupakan hasil dari pelaksanaan tugas dan kompetensi guru Pendidikan Agama Islam di SMK Islam Al-Irsyad Kebon Kongok Suka Makmur Kecamatan Gerung Lombok Barat.

Untuk mengetahui data tersebut penulis melihat keadaan dan besarnya populasi dilapangan. Adapun banyak dan besarnya populasi dilapangan penelitian terdiri dari 3 kelas dengan jumlah siswa sebanyak 118 orang dengan perincian kelas VII 51 orang, kelas VIII 43 orang dan kelas IX sebanyak 24 orang, jumlah yang seperti ini untuk peneliti dirasa cukup besar dan banyak sehingga diambillah cara termudah dalam penelitian ini dengan menggunakan penelitian sampel. Dan untuk langkah berikutnya peneliti mengadakan penelitian tentang besarnya sampel. Untuk menentukan sampel penelitian ini penulis telah menerapkan subyek penelitian yakni hanya pada kelas VIII yang terdiri dari 46 orang siswa.

\title{
2. Penerapan Kompetensi Guru Pendidikan Agama Islam dalam meningkatkan prestasi belajar siswa SMK Islam Al-Irsyad Kebon Kongok
}

Mendidik merupakan suatu pekerjaan yang dilandasi dengan profesi untuk dapat mengajar. Suatu profesi memerlukan kompetensi khusus, yaitu kemampuan dasar berupa keterampilan menjalankan rutinitas sesuai dengan petunjuk, aturan dan prosedur tekhnis. Seorang guru memerlukan kompetensi khusus yang berkenaan dengan tugasnya. Hal itu karena pendidikan tidak terjadi secara alami, tetapi dengan di sengaja (disadari). Oleh karena itu peranan guru sangatlah besar bai melalui pelaksanaan tugas dengan penuh tanggung jawab maupun dengan kompetensi yang cukup tinggi. Dalam wawancara yang dilakukan penulis dengan wakil kepala madrasah bagian kurikulum, mengenai peranan tugas dan kompetensi bagi perkembangan prestasi belajar peserta didik menyatakan bahwa: tugas dan kompetensi guru sangat mendukung bagi keberhasilan siswa. Sebab berdasarkan kurikulum 2006 yaitu Kurikulum Tingkat Satuan Pendidikan, memberikan pengajaran atau bimbingan kepada siswa, seorang guru dituntut bahkan harus memiliki kompetensi yang tinggi, dalam pelaksanaan tugasnya seorang guru juga harus disiplin dan penuh tanggung jawab. Oleh karena itu semua guru hendaknya teus dapat melaksanakan tugas dan kompetensinya dengan baik sehingga keberhasilan dapat tercapai dengan baik pula. Sebagai guru tentunya memiliki tugas dan kompetensi yang sama seperti guru-guru yang lain. Berdasarkan metodologi pengajaran agama Islam, kompetensi guru meliputi pokok-pokok sebagai berikut:

1) Menguasai bahan pelajaran yang akan diajarkan kepada peserta didik. Seorang guru tidak hanya menguasai seluk beluk bahan yang diajarkan

\author{
96 | Edisi 3 No.1 Agustus $2020-$ Januari 2021
}


tetapi juga meyakini bahwa apa yang diajarkan memiliki kebenaran berdasarkan sumber yang dipercaya.

2) Memiliki kemampuan menyusun rencana pelaksanaan pembelajaran dengan mengetahui arti dan tujuan perencanaan.

3) Memiliki kreativitas untuk menciptakan dan menumbuhkan kegiatan peserta didik, kemampuan mengubah perencanaan apabila diperlukan dan kemampuan mengelola kelas.

4) Memiliki kemampuan melakukan penilaian kemajuan belajar peserta didik dengan memanfaatkan secara kreatif bentuk-bentuk penilaian yang ada.

5) Selain itu guru Pendidikan Agama Islam harus siap apabila sewaktu-waktu ada kegiatan kerohanian di luar jam pelajaran atau dalam kegiatan ekstra kurikuler untuk memberikan pengarahan apabila dibutuhkan.

\section{Analisis Hasil Penelitian}

Dari hasil penelitian yang dilakukan diperoleh hasil belajar siswa atau prestasi yang diperoleh siswa dalam bidang pendidikan agama islam adalah sebagai berikut:

1) Hasil belajar siswa bidang studdi qur'an hadist nilai rata-ratanya adalah 71.63

2) Hasil belajar siswa bidang studi fiqih nilai rata-ratanya adalah 75.33

3) Hasil belajar siswa bidang studi aqidah akhlak nilai rata-ratanya adalah 71.10

4) Hasil belajar siswa bidang studi bahasa arab nilai rata-ratanya adalah 70.78

Dengan melihat dari nilai rata-rata yang diperoleh oleh siswa dalam setiap bidang studi pendidikan agama islam dapat kita katakan bahwa kompetensi guru dalam meningkatkan prestasi belajar siswa sudah tercapai,hal ini terlihat dari nilai rata-rata siswa yang berada di atas nilai ketuntasan minimal yang ditetapkan oleh sekolah yakni untuk bidang studi agama nilai ketuntasan minimal adalah 70.00 .

\section{Pembahasan}

Potensi guru pendidikan agama islam dalam kompetensi kepribadian adalah bahwa beliau adalah seorang guru dengan latar belakang sarjana hukum islam, sudah barang tentu beliau menguasai hukum-hukum yang berkaitan dengan hukum islam, kompetensi keperibadian merupakan perwujudan dari kewibawaan seorang guru, dan memiliki kompetensi itu yaitu beliau mampu memberikan contoh pribadi yang baik, sehingga beliau berwibawa dikalangan para siswa dan guru. Sementara kompetensi pedagogik yang beliau miliki adalah beliau mampu memberikan pemahaman kepada para peserta didik dan mengelola pembelajaran yang mendidik dan dialogis. Kompetensi profesional yang beliau terapkan adalah beliau mampu menguasai materi pemnelajaran dengan luas sehingga peserta didik dapat lebih mudah mengerti dan memhamai pelajaran yang diberikan. Potensi kompetensi sosial yang dimiliki oleh $\mathrm{H}$. Zainul Irfan, S.Pd., MM, adalah beliau merupakan sosok yang mudah bergaul baik dengan peserta didik maupun dengan sesama pendidik, dimasyarakatpun beliau sering dipercaya untuk membaca khotbah dimasjid, sehingga pergaulan dengan orang tua siswa pun luas. Dengan 
potensi kompetensi yang dimiliki oleh guru pendidikan agama islam ini prestasi belajar siswa untuk bidang studi ini dikatakan berhasil hal ini dilihat dari nilai rata-rata yang diperoleh siswa adalah 71.63.

Potensi guru bidang studi pendidikan agama islam kompetensi kepribadian adalah mempunyai kepribadian yang mantap dan stabil dan memiliki etos kerja yang tinggi sehingga beliau menjadi contoh yang baik bagi peserta didik. Kompetensi pedagogik yang beliau miliki adalah membuat perancangan dan pelaksanaan pembelajaran, melakukan evaluasi pembelajaran hal ini dapat menegembangkan potensi yang dimiliki oleh peserta didik untuk megaktualisasikan dirinya. Kompetensi professional yang beliau miliki adalah menguasai kurikulum yang diterapkan oleh sekolah sehingga dalam penyampaian pembelajaran dan batas-batas pembelajaran dilakukan dengan tepat, sehingga jika ada evaluasi siswa tidak merasa kesulitan karena semua materi sudah tuntas diajarkan. Kompetensi sosial yang dikembangkan adalah mampu berkomunikasi dengan efektif baik dilingkungan sekolah maupun dimasyarakat, mempunyai kemampuan agama yang diperhitungkan oleh orang lain sehingga sering dipercaya oleh masyarakat untuk mengurusi hari-hari besar agama islam. Dari keempat kompetensi yang dimiliki guru mampu meningkatkan prestasi belajar siswa hal ini dapat dilihat dari nilai rata-rata yang diperoleh siswa dalam mata pelajaran Agama adalah 75.33 .

Potensi guru PKn dalam kompetensi kepribadian adalah beliau memiliki perilaku yang positif terhadap peserta didik dan memiliki perilaku yang disegani. Kompetensi pedagogik yang dimiliki adalah mampumerancang dan merancanakan pembelajaran dengan baik. Kompetesni professional yang potensial pada diri beliau adalah menguasai materi pembelajaran terkait dengan latar belakang ilmu yang dimilki. Kompetensi sosial yang potensial adalah beliau dipercaya oleh masyarakat dan mempunyai pergaulan yang luas. Dari kompetensi yang dimiliki ini adalah mampu untuk meningkatkan prestasi belajar siswa hal ini terlihat dengan nilai rata-rata mata pelajaran PKn adalah 71.10 dan nilai Bidang Studi Bahasa Indonesis 70.78.

\section{E. Kesimpulan}

Berdasarkan hasil penelitian mengenai kompetensi guru dapat diambil beberapa kesimpulan:

1) Pelaksanaan kompetensi guru akan sangat mendukung dalam upaya pengembangan prestasi belajar siswa. Sehingga setiap guru hendaknya dapat melaksanakan tugasnya dengan tanggung jawab yang penuh serta memiliki kompetensi yang tinggi.

2) Peranan tugas dan kompetensi guru hendaknya dapat dilaksanakan dengan sebaik-banyaknya. Karena dengan tugasnya guru dapat menyalurkan kemampuannya dengan penuh tanggung jawab dan disiplin, dan dengan kompetensi yang dia miliki akan dapat mencapai keberhasilan bagi siswa sesuai dengan apa yang diharapkan dan diupayakan. 


\section{Daftar Rujukan}

Aqib, Zainal. Profesionalisme Guru Dalam Pembelajaran. Insan Cendekia, Jakarta. Arikunto, Suharsimi. Prosedur Penelitian Teori dan Praktik. Rineka Cipta, Jakarta. 2006.

Darajat, Zakiah. Metodik Khusus Pengajaran Agama Islam. Bumi Aksara, Jakarta. 2004.

Departemen Agama RI. Metodologi Pendidikan Agama Islam. Dirjen Bimbaga Islam, Jakarta. 2002.

Djamarah, Saiful Bahri. Prestasi Belajar dan Kompetensi Guru, Usaha Nasional, Surabaya. 1994.

E. Mulyasa. Kurikulum Berbasis Kompetensi. Remaja Rosdakarya, Bandung, 2004.

Moleong, Lexy J. Metode Penelitian. Remaja Rosdakarya, Bandung : 2002.

Muhaimin. Paradigma Pendidikan Agama Islam. Remaja Rosdakarya, Bandung. 2004.

Nazir, Moh. Metode Penelitian. Ghalia Indonesia, Jakarta. 2003.

Shaleh, Abdul Rahman. Paradigma Pendidikan Agama Islam. Remaja Rosdakarya, Bandung. 2004.

Suderajat, Hari. Manajemen Peningkatan Mutu Berbasis Sekolah. Cipta Cekas Grafika, Bandung. 2005.

Sukmadinata, Nana Syaodih. Landasan Psikologi Proses Pendidikan. Remaja Rosdakarya, Bandung. 2004.

Sutrisno Hadi, 1991, Statistik Jilid II, Yayasan Penerbitan Fakultas Psikologi UGM, Yogyakarta.

Syar'i, Ahmad. Filsafat Pendidikan Agama Islam. Pustaka Firdaus, Jakarta. 2005.

Usman, Moh. Uzer. Menjadi Guru Profesional. Remaja Rosdakarya, Bandung. 2001. 
Jurnal Lentera

Jurnal Studi Pendidikan

100|Edisi 3 No.1 Agustus 2020 -Januari 2021

http://ojs.yplppgriksb.or.id/index.php/lentera/index 